ACTA UNIVERSITATIS LODZIENSIS

FOLIA LITTERARIA POLONICA 1(31) 2016

http://dx.doi.org/10.18778/1505-9057.31.08

Barbara Sobczak $^{*}$

\title{
News telewizyjny jako akt retoryczny
}

\section{Ustalenia terminologiczne}

Swoje rozważania rozpocznę od ustaleń terminologicznych. News traktuję jako „relację o wydarzeniu”. Traktowanie newsa jako relacji o wydarzeniu odwołuje się do sformułowanego przez Wilbura Schramma w tekście The Nature of $\mathrm{News}^{2}$ rozróżnienia między wydarzeniem a newsem. News dla Schramma to nie samo wydarzenie, lecz coś, co postrzega się po nim. Jest to istotna kwestia, dlatego że zarówno w życiu codziennym, jak i w badaniach nad mediami news funkcjonuje również w znaczeniu „niezwykłe wydarzenie, nowa wiadomość”’. Dodatkowo, przyjmuję, że by taka relacja o wydarzeniu mogła być newsem, musi zostać rozpowszechniona przez media i stać się aktem publicznym ${ }^{4}$. W odniesieniu do tych ustaleń, news telewizyjny to dla mnie relacja o wydarzeniu zbudowana zazwyczaj z zapowiedzi ${ }^{5}$ i krótkiego, kilkuminutowego materiału filmowego (nazywanego czasem felietonem) będącego rezultatem pracy reporterskiej, wyemitowana w telewizji, zazwyczaj jako jeden z elementów

*Dr, e-mail: barbarasobczak@o2.pl; Uniwersytet im. A. Mickiewicza w Poznaniu, Wydział Filologii Polskiej i Klasycznej, Instytut Filologii Polskiej; 61-701 Poznań, ul. Fredry 10.

${ }^{1}$ Jest to sposób rozumienia newsa uznawany przez badaczy mediów (zob. I. Tetelowska, Informacja jako odrębny gatunek prasowy, [w:] taż, Szkice prasoznawcze, Ośrodek Badań Prasoznawczych, Kraków 1972, s. 237; J. Fras, Dziennikarski warsztat językowy, Wydawnictwo UWr, Wrocław 1999, s. 78; W. Furman, A. Kaliszewski, K. Wolny-Zmorzyński, Gatunki dziennikarskie. Specyfika ich tworzenia i redagowania, Wyższa Szkoła Zarządzania w Rzeszowie, Rzeszów 2000, s. 33; ale też: M. Palczewski, Cała prawda o newsie. Definicja-granice poznania-konteksty, [w:] Teorie komunikacji i mediów, t. 4, red. M. Graszewicz, J. Jastrzębski, Oficyna Wydawnicza ATUT, Wrocław 2011, s. 54).

2 W. Schramm, The Nature of News, ,Journalism Quarterly” 1949, No 26, p. 259.

${ }^{3}$ Pisze o tym m.in. Monika Worsowicz: „W mowie potocznej «mieć newsa» oznacza mieć wiadomość, nową wiadomość, zwłaszcza niezwykłą, zaskakującą” (M. Worsowicz, „Mam newsa!”, czyli o problemie naukowców i marzeniu dziennikarzy, [w:] News wobec wyzwań XXI wieku, red. M. Palczewski, M. Worsowicz, Akademia Humanistyczno-Ekonomiczna, Łódź 2010, s. 9-24).

${ }^{4}$ M. Palczewski, dz. cyt., s. 54 .

${ }^{5} \mathrm{~W}$ slangu dziennikarskim jest to tak zwana „biała” - tekst czytany przez prezentera w studiu. 
w strukturze magazynu informacyjnego, ale również jako element bloków programowych telewizji informacyjnych. Materiał filmowy nie jest inwariantnym elementem newsa, bywają newsy pozbawione ilustracji filmowej, chociaż zdarza się to rzadko. Pomimo iż news telewizyjny stanowi zamkniętą całość tematyczną i strukturalną, w zasadzie nie funkcjonuje samodzielnie. Jest częścią większej całości i jako taka istnieje w układzie innych newsów (np. w obrębie magazynu informacyjnego), co nie jest bez znaczenia, dlatego że kontekst ten ma wpływ na interpretowanie przekazu i tworzone przez niego sensy.

Akt retoryczny natomiast rozumiem jako użycie środków symbolicznych (w tym języka i obrazu) dla osiągnięcia zamierzonego celu. Zakładam, że aby zakwalifikować jakiś akt jako „retoryczny”, musi być on, po pierwsze, zamierzony, po drugie - być odpowiedzią na określoną sytuację (a więc muszą istnieć określone czynniki historyczne, polityczne lub kulturowe, które są pretekstem powstania aktu) i po trzecie - być adresowany do odbiorców ${ }^{6}$. Retoryka to proces, w którym za pomocą języka i innych środków symbolicznych organizuje się doświadczenie i przekazuje je innym, ale tak, by osiągnąć zamierzone efekty? Jest więc to proces nastawiony na perswazję̧, a wybór środków zależy od tego, kto mówi, do kogo, w jakim celu i w jakich okolicznościach.

\section{Cel newsa}

Nadrzędnym celem newsa jest przekazanie informacji o czymś. O pojedynczym zdarzeniu, kilku zdarzeniach, ale też procesach, zjawiskach lub problemach. Ten cel eksponowany jest przez kontekst, w jakim news jest ,używany”. Emitowany jest bowiem, jak już zostało powiedziane, najczęściej w obrębie magazynu informacyjnego. „Informacyjny” oznacza tutaj - podporządkowany funkcji powiadamiania o zdarzeniach ${ }^{9}$. Ma to swoje określone skutki pragmatyczne. Wymaga się bowiem od publikacji informacyjnej, by była ona pozbawiona subiektywnych

\footnotetext{
${ }^{6}$ Por. K.K. Campbell, S.S. Huxman, T.R. Burkholder, The Rhetorical Act. Thinking, Speaking and Writing Critically, Wadsworth, Belmont 2003, pp. 27-28.

${ }^{7}$ Zob. K.K. Campbell, Modern Rhetoric, [in:] Encyclopedia of Rhetoric, ed. T.O. Sloane, Oxford University Press, New York 2001.

${ }^{8}$ Perswazję jako cel retoryki wskazywał już Arystoteles, mówiąc, że retoryka to „dostrzeganie tego, co odnośnie do każdego przedmiotu może być przekonywające” (Arystoteles, Retoryka, 1355b, [w:] tenże, Retoryka. Retoryka dla Aleksandra. Poetyka, przeł. H. Podbielski, Wydawnictwo Naukowe PWN, Warszawa 2004, s. 47).

${ }^{9}$ J. Maziarski, Informacja, [w:] Encyklopedia wiedzy o prasie, red. J. Maślanka, Ossolineum, Wrocław 1976, s. 107-109; Z. Bauer, Gatunki dziennikarskie, [w:] Dziennikarstwo i świat mediów, red. Z. Bauer, E. Chudziński, Universitas, Kraków 2000, s. 143-173; M. Wojtak, Gatunki prasowe, Wydawnictwo UMCS, Lublin 2004, s. 29-33.
} 
form podawczych, dążyła do maksymalnego obiektywizmu (z naciskiem położonym na bezstronność nadawcy - dziennikarza ${ }^{10}$ ) i uwydatniała przede wszystkim funkcje poznawcze. Podkreśla się, że celem informacji jest ukazywanie zjawisk, w przeciwieństwie do publicystyki, która ma je komentować ${ }^{11}$. Niektórzy, jak Walery Pisarek, dodają jeszcze, że by mogła być wyczerpująca, musi odpowiadać na pytania: kto, co, gdzie, kiedy, dlaczego i z jakim skutkiem ${ }^{12}$.

Można więc przyjąć, że dominującą funkcją newsa będzie funkcja informacyjna, funkcja docere. Nie sposób jednak, mówiąc o celu newsa, pominąc mechanizmów decydujących o tym, co i dlaczego staje się jego przedmiotem oraz tego, jak informuje on o świecie. Jak pokazują badania mediów ${ }^{13}$, programy informacyjne mają bardzo wysoki status wśród przekazów medialnych i są jednym z najważniejszych źródeł wiedzy ludzi o tym, co dzieje się na świecie. News jest więc narzędziem kierowania uwagi odbiorcy, wprowadzania pewnego porządku i sensu do jego sposobu doświadczania i rozumienia świata. Znaczące są tutaj przede wszystkim działania w zakresie gatekeepingu, a więc selekcja informacji i związane z nią fokusowanie uwagi odbiorcy na wybranych fragmentach rzeczywistości. W tym kontekście bardzo ważna byłaby figura synekdochy. News pokazuje część zamiast całości i chodzi o to, by ta część oddawała istotę całości, a nie ją przekłamywała. Istotna w przypadku przekazu telewizyjnego jest też jego sugestywna audiowizualna forma, która, dzięki wykorzystaniu obrazu, pozwala na zbudowanie w widzu przekonania o tym, że nie tylko jest on poinformowany, co dzieje się w świecie, ale też, że obserwuje rzeczywistość i uczestniczy w zdarzeniach, do których nie ma dostępu. Obraz ma, jak mówi Pierre Bourdieu, szczególną zdolność wytwarzania „efektu rzeczywistości”14. Telewizja sprawia, że ludzie widzą coś i wierzą w to, co ona pokazuje. Wierzą, że oglądając newsy, poznają fakty. Fakty rozumiane jako ,synonim czegoś, co po prostu jest, dzieje

${ }^{10}$ M. Szulczewski, Informacja, [w:] Teoria i praktyka dziennikarstwa. Wybrane zagadnienia, red. B. Golka, M. Kafel, Z. Mitzner, PWN, Warszawa 1964, s. 91-97.

${ }^{11}$ W. Furman, A. Kaliszewski, K. Wolny-Zmorzyński, dz. cyt., s. 26.

${ }^{12}$ W. Pisarek, Podstawy retoryki dziennikarskiej, [w:] Dziennikarstwo i świat mediów. Nowa edycja, red. Z. Bauer, E. Chudziński, wyd. 4 zm., uzup., rozszerz., Universitas, Kraków 2008, s. 371. Zob. też: J. Liberek, Informacja czy manipulacja? Jak „, Gazeta Wyborcza” pisze o Kościele, „Więź” 1992, nr 11, s. 21-25; A. Zwoliński, Stowo w relacjach społecznych, WAM, Kraków 2003, s. 204-210.

${ }^{13}$ M. Lisowska-Magdziarz, Media powszednie. Środki komunikowania masowego i szerokie paradygmaty medialne $w$ życiu codziennym Polaków u progu XXI wieku, Wydawnictwo UJ, Kraków 2008, s. 174; L. Miś, Demonstracje retoryczne $w$ telewizyjnym programie informacyjnym „Fakty”- TVN, [w:] Sztuka perswazji. Socjologiczne, psychologiczne i lingwistyczne aspekty komunikowania perswazyjnego, red. R. Karpiel, K. Leszczyńska, Zakład Wydawniczy „Nomos”, Kraków 2004, s. 323-324.

${ }^{14} \mathrm{P}$. Bourdieu, O telewizji. Panowanie dziennikarstwa, przeł. K. Sztandar-Sztanderska, A. Ziółkowska, red. M. Jacyno, Wydawnictwo Naukowe PWN, Warszawa 2009, s. 47. 
się lub się zdarzyło"15. Jest to oczywiście, jak pisze Marek Palczewski ${ }^{16}$, jeden z mitów o newsach, bo fakty, co zostało już nie raz przedyskutowane w nauce, nie są czymś niezależnym od obserwatora, neutralnym, danym obiektywnie i raz na zawsze, ale są interpretacją zdarzeń. Wpisują się zawsze w jakiś system wartości, są poddawane selekcji i rozmaicie niuansowane. Są w końcu opisywane w języku (nawet jeśli jest to obraz) i jako takie zawierają ładunek emocjonalny i aksjologiczny ${ }^{17}$. Widzowie w newsie obserwują więc tylko pewną wersję rzeczywistości, którą (w wyniku selekcji i interpretacji informacji) przygotował dla nich nadawca. I w tym kryje się potencjał perswazyjny newsa:

dysponując wyjątkową siłą, którą daje obraz, telewizyjni dziennikarze mogą wytwarzać skutki niemające sobie równych. [...] Ta władza przedstawiania może skutkować mobilizacją. Może powołać do życia jakieś idee lub przedstawienia, ale również grupy. Sensacyjki, codzienne incydenty lub wypadki mogą mieć implikacje polityczne, etyczne, mogą wywoływać silne uczucia ${ }^{18}$.

Decyzja o tym, które wydarzenia staną się tematem newsa, jest decyzją polityczną nadawcy medialnego. Bywa tak, że o pewnych zdarzeniach, chociaż spełniają kryteria aktualności, sensacyjności czy ważności publicznej, w ogóle się nie mówi - nie podaje się na przykład informacji niewygodnych dla jakiejś grupy interesów, władzy, właściciela środka przekazu czy po prostu szefa. Takie przypadki opisywane są jako przykłady manipulacji w mediach (tzw. przemilczenie ${ }^{19}$ ), ale bywa też tak, że celowo nagłaśnia się pewne wydarzenia i podkreśla ich ważność ${ }^{20}$.

Newsy kreują więc pewną wizję świata, ale też chcą, by odbiorca bezwarunkowo zaakceptował tę wizję, przyjął prezentowane sądy i opinie i w tym celu posługują się rozmaitymi strategiami uwiarygodniającymi. Jest to obszar, na którym ujawniają się funkcje movere i delectare.

Celem newsa jest zatem dostarczyć informację. Ale celem newsa jest też:

- wykreować jakiś obraz świata poprzez wybór tematów, selekcję informacji i sposób pokazania rzeczywistości (funkcja kreacyjna newsa ${ }^{21}$;

${ }^{15}$ M. Karwat, Medialna mitologia faktów, [w:] Współczesne oblicza mediów, red. J. Marszałek-Kawa, Wydawnictwo Adam Marszałek, Toruń 2005, s. 45.

${ }^{16}$ M. Palczewski, dz. cyt., s. 55-56.

${ }^{17}$ Tamże, s. 56.

${ }^{18}$ P. Bourdieu, s. 46-47.

${ }^{19}$ M. Iłowiecki, Krzywe zwierciadło. O manipulacji w mediach, Wydawnictwo Archidiecezji Lubelskiej Gaudium, Lublin 2003, s. 114.

${ }^{20} \mathrm{O}$ problemie desepizacji, czyli nagłaśnianiu w mediach tego, co nieważne, pisali M. Czyżewski, K. Dunin, A. Piotrowski (tychże: Cudze problemy. O ważności tego, co nieważne. Analiza dyskursu publicznego w Polsce, Wydawnictwa Akademickie i Profesjonalne, Warszawa 2010).

${ }^{21}$ Janusza Gajda wyróżnia pięć funkcji kulturotwórczych mediów w ogóle: funkcję upowszechniania różnorodnych treści, stymulacyjną (realizującą się poprzez pobudzanie odbiorców 
- przekazać pewne wzory do naśladowania, a nawet pouczać, jak żyć (funkcja wzorcotwórcza). Newsy pokazują „bohaterów” lub „antybohaterów” życia codziennego. Są to materiały o osobach, które uratowały kogoś z narażeniem życia, pomagają w sytuacji katastrofy, wypadku albo odwrotnie - nie zareagowały w sytuacji krytycznej i na przykład nie pomogły osobie zaatakowanej na ulicy;

- stymulować odbiorców do określonych zachowań, prowokować do refleksji, dawać poczucie więzi społecznej, poprzez poruszanie tematów bliskich określonym grupom społecznym, z którymi widz może się utożsamić (funkcja stymulacyjna). Pokazuje się ludzi w trudnych sytuacjach życiowych - podczas walki z chorobą, po wypadku, po kataklizmie, takim jak pożar czy powódź. Takie przekazy są jednocześnie nie wprost sformułowanym, ale apelem o pomoc dla poszkodowanych;

- ocenić zdarzenia (funkcja wartościująca). Oceny w newsie są formułowane w dwojaki sposób: wprost - w komentarzach odautorskich (zazwyczaj w stand-upie lub w formie cytatu) i w setkach; oraz w sposób pośredni - poprzez sposób przedstawienia tematu. Na przykład poprzez zastosowanie takich figur, jak ironia, co pozwala domyślić się czegoś innego niż to, o czym dziennikarz mówi wprost, lub hiperbola - gdy pokazuje się pewne zdarzenia w krzywym zwierciadle, wyolbrzymia je, by osiągnąc efekt satyryczny;

- i w końcu ma on też sprawiać przyjemność (funkcja delectare). Funkcja ta realizowana może być w dwojaki sposób: poprzez dobór tematów - gdy mówi się np. o strojach gwiazd na czerwonym dywanie podczas rozdania Oscarów, muzyce disco-polo czy o memach internetowych; ale też poprzez styl przekazu - gdy uruchamia się quasi-kabaretową konwencję komunikowania się z odbiorcami na tematy niekoniecznie zabawne. Coraz częstej na przykład informacja polityczna zostaje uzupełniona cytatami filmowymi, na przykład z filmów Stanisława Barei czy Juliusza Machulskiego.

\section{News a potrzeby odbiorcy}

Patrząc na newsy z perspektywy retorycznej, należy zapytać, na jaką sytuację krytyczną (w znaczeniu Lloyda Bitzera ${ }^{22}$ ) i na jakie potrzeby są one odpowiedzią? Andrzej Kudra ${ }^{23}$, podejmując próbę zdefiniowania newsa, postawił tezę,

do aktywnego odbioru i pełniejszego uczestnictwa w kulturze), wzorcotwórczą (wypełnia się ona poprzez propagowanie wzorów postępowania), interpersonalną (realizowaną poprzez wszechobecność mediów, dzięki którym człowiek może poznawać życie innych ludzi) i ludyczną (zob. J. Gajda, Media w edukacji, Oficyna Wydawnicza Impuls, Gdańsk 2007).

${ }^{22}$ L.F. Bitzer, The Rhetorical Situation, „Philosophy \& Rhetoric” 1968, No 1, pp. 1-14.

23 A. Kudra, News jako funkcja, „Acta Universitatis Lodziensis. Folia Literaria Polonica” 2010, nr 13, s. 401-403. 
że w aspekcie komunikacyjnym news mieści się w komunikacji, którą można nazwać apodyktyczną albo komunikacją dyktatu komunikacyjnego. Oznacza to, że wiadomość musi się pojawić. Na wiadomość czeka odbiorca i musi ona wypełnić swoje informacyjne funkcje. Tę tezę potwierdzają badania Małgorzaty Lisowskiej-Magdziarz, która pokazuje, że istnieje coś takiego, jak społeczny przymus bycia poinformowanym. Bycie poinformowanym jest rodzajem kulturowego obowiązku, a jednym z głównych źródeł wiedzy jest telewizja ${ }^{24}$, zwłaszcza dla odbiorców z klasy średniej, dysponujących skromniejszym kapitałem kulturowym $^{25}$. Telewizja dostarcza wiedzy o ważnych wydarzeniach, ale też informacji istotnych dla pracy, nauki, rozrywki i funkcjonowania społecznego ludzi. Duża część ludzi jest całkowicie zależna od telewizji, jeśli chodzi o zdobywanie wiedzy, dlatego telewizja dysponuje rodzajem monopolu na kształtowanie umysłów ludzi ${ }^{26}$. To zatem, czego potrzebuje odbiorca, to wiedza, i tę potrzebę zaspokaja news. Trzeba jednak pamiętać, że wiedza, jakiej dostarczają newsy, to nie epistémé, odwołując się do platońskiego podziału, a więc nie wiedza pewna, uzasadniona, oparta na poznaniu rozumowym, tylko dóxa - mniemanie, poznanie niepewne, zawierające możliwość błędu; pogląd, który można obalić ${ }^{27}$. Wiedza newsowa jest przede wszystkim wiedzą krótkotrwałą - wszak newsy szybko się starzeją i w zasadzie już w momencie opublikowania tracą swoją aktualność. To też wiedza powierzchowna, ponieważ warunki komunikacji, w tym przede wszystkim ograniczenia czasowe, nie pozwalają na analizę zjawisk. Poza tym, uproszczona - znowu: nie bez znaczenia są tutaj determinanty sytuacji komunikacyjnej, gdyż dziennikarz, tworząc przekaz, musi uwzględnić kompetencje mentalne odbiorcy i jego zdolność rozumienia przekazu telewizyjnego. Dlatego newsy częściej dotyczą pojedynczych lub kilku powiązanych ze sobą zdarzeń niż zjawisk, procesów czy problemów. Skupiają się na tym, co bieżące, nie uwzględniając przyczyn historycznych, strukturalnych ani szerszego kontekstu środowiska społeczno-politycznego i zachodzących w nim procesów ${ }^{28}$. Mówienie o zja-

${ }^{24}$ Badania TNS Polska pokazują, że mimo coraz większej liczby użytkowników internetu, nadal 76\% Polaków codziennie ogląda telewizję (http://www.tnsglobal.pl/informacje/telewizjatrzyma-sie-mocno-nowe-urzadzenia-przynosza-nowe-wzorce-ogladania-infografika/ [dostęp: 21.03.2015]). Poza tym z innych badań TNS wynika, że głównym źródłem codziennych informacji dla badanych są „Wiadomości” w TVP1 (22 proc.) i „Fakty” w TVN (20 proc.) (http://wyborcza. pl/1,76842,15095765,Dla_60_proc__Polakow_TVP_jest_dobra_telewizja_publiczna_html [dostęp: 21.03.2015]).

${ }^{25}$ Im wyższe wykształcenie odbiorców, bogatsze konteksty społeczne, tym wyższy jest krytycyzm widzów w stosunku do informacji medialnych i tym mocniejszy nacisk kładą oni na inne źródła wiedzy i aktualności (M. Lisowska-Magdziarz, dz. cyt., s. $174-179)$.

${ }^{26}$ P. Bourdieu, dz. cyt., s. 43.

${ }^{27}$ M. Palczewski, dz. cyt., s. 59-60.

${ }^{28}$ Przykładem na taki uproszczony sposób pokazywania rzeczywistości jest news wyemitowany w TVN24 20 marca 2015 r. Tematem newsa są egzaminy kończące pewien etap edukacji w Indiach; tekstowi towarzyszy materiał filmowy, na którym widzimy wspinających się po 
wiskach i problemach wymaga bowiem rozwiniętych kompetencji poznawczych, mówienie o zdarzeniach - tylko uważnego śledzenia akcji ${ }^{29}$.

Jest to w końcu wiedza selektywna. News powstaje jako reakcja na jaką́s sytuację, wydarzenie, ale musi to być wydarzenie wyjątkowe, inne, niezwykłe, niecodzienne. Ta wyjątkowość może oznaczać coś nienormalnego, a nawet dewiacyjnego; ale też może wynikać z ważności wydarzenia, jego znaczenia dla jakiejś wspólnoty, gdy na przykład dotyczy ważnych osób lub większości. Praktyka dziennikarska i deontologia mediów wypracowały na przestrzeni dziesięcioleci kryteria pozwalające wskazać, jakiego rodzaju wydarzenia mogą czy powinny być pretekstami do tego, by o nich mówić w mediach. Są to kryteria, które telewizja w dużej części zapożyczyła od prasy. Przyjmuje się zatem, że aby wydarzenie mogło być tematem newsa, powinno być: 1) niezwykłe - jak mówi Bourdieu, dzienniki muszą nadawać codziennie coś nie-codziennego ${ }^{30}$;2) krótkotrwałe; 3) zachodzące pomiędzy kolejnymi wydaniami audycji informacyjnych, a więc aktualne; 5) ważne dla odbiorcy; 6) przewidywalne lub pożądane albo 7) nagłe i niespodziewane; 8) powtarzalne; 9) kontrastujące $\mathrm{z}$ innymi wiadomościami; 10) dotyczące elit społecznych i 11) państw odgrywających ważną rolę w polityce, w końcu: 12) spersonalizowane i 13) negatywne ${ }^{31}$. Kryteria te uwzględniają potencjalne zainteresowania odbiorców telewizyjnych. Badania mediów, ale też doświadczenia psychologów pokazują, że szczególne zainteresowanie ${ }^{32}$, ale też doświadczenia psychologów, szczególne zainteresowanie większości ludzi budzi: 1) to, co jest im najbliższe - dlatego newsy częściej dotyczą spraw krajowych niż zagranicznych; 2) to, co konkretne i bliskie indywidualnemu doświadczeniu,

ścianach budynku ludzi, podających przez okna karteczki: „Oszukiwanie na szkolnych testach nie jest rzadką praktyką w Indiach. Pomysłowość uczniów szkół średnich w stanie Bihar - oraz ich rodziców - przyćmiła jednak wszystkie dotychczasowe osiągnięcia. Nauczyciele złapali setki uczniów usiłujących wnieść na salę egzaminacyjną nie tylko ściągi, ale i całe podręczniki. Ich rodzice i znajomi wspinali się natomiast po ścianach szkół, by przez okno podać ściągawki. Blisko 1,5 mln uczniów w ponad 1200 szkołach w stanie Bihar zdaje w tym roku egzamin na koniec 10. klasy. Sprawdzianowi towarzyszy ogromna presja, bo jego zdanie jest warunkiem kontynuowania nauki”. Problem potraktowano jako sensacyjną ciekawostkę, natomiast pokazanie kontekstu pozwoliłoby powiedzieć coś więcej o przyczynach takich zachowań, a nawet zmienić charakter opisanego zdarzenia. Nie uwzględniono w ogóle sytuacji społeczno-demograficznej w Indiach i tego, że motywacją do takich zachowań jest ogromna, w Polsce czy Europie niewyobrażalna, konkurencja na rynku pracy. Wyniki egzaminu decydują o przyszłości dziecka w kraju, w którym na przykład o jedno stanowisko w służbie administracyjnej stara się średnio 10 tys. osób.

${ }^{29}$ Na tę właściwość newsów, zwłaszcza polskich, zwrócił uwagę Maciej Mrozowski, porównując newsy polskie z newsami niemieckimi, brytyjskimi i francuskimi. Newsy polskie są zazwyczaj faktograficzne - przedstawiają jedno lub kilka zdarzeń, newsy zagraniczne są częściej analizą procesów i zjawisk (M. Mrozowski, Telewizyjne programy informacyjne - polskie i zagraniczne (analiza porównawcza), „Studia Medioznawcze” 2009, nr 3, s. 37-38).

${ }^{30}$ P. Bourdieu, dz. cyt., s. 46.

${ }^{31}$ J. Fras, dz. cyt., s. 78. Jak widać, niektóre z tych kryteriów wzajemnie się wykluczają.

${ }^{32}$ W. Pisarek, dz. cyt., s. 369. 
dlatego w newsach pokazuje się problemy natury ogólnej na przykładzie losów zwykłych ludzi (tzw. personalizacja); 3) to, co rzeczywiste, a więc to, co się naprawdę zdarzyło, a nie to, co zdarzyć by się mogło; 4) to, co konfliktowe, w przeciwieństwie do tego, co zgodne; 5) to, co nowe i nieoczekiwane oraz 6) to, co wesołe i śmieszne, w przeciwieństwie do tego, co poważne i całkiem serio, dlatego coraz więcej w newsach infotainmentu.

W końcu, wiedza newsowa jest nieweryfikowalna, zwłaszcza dla odbiorcy, a to otwiera niebezpieczne pole do perswazyjnych nadużyć, a nawet manipulacji. W kulturze tradycyjnej zdawało się, że odróżnienie prawdy i fałszu, tego, co jest, $\mathrm{i}$ tego, co nie jest, jest prostsze z uwagi na to, że kultura i wartości konstruowane były z jednego punktu widzenia, np. z punktu widzenia warstw, które znajdowały się u władzy. Dziś nie ma jednego środka nadawczego. Mediów jest wiele, każde z nich konstruuje inną opowieść o świecie i nie sposób, aby odbiorca medialny był w stanie zweryfikować, ,gdzie leży prawda”. Mimo to, odbiorcy są często głęboko przekonani, że pewne stacje bardziej kłamią niż inne, a inne są bardziej prawdomówne. Można tutaj przytoczyć casus odbiorców telewizji Trwam, którzy powiedzą, że TVN kłamie, ale nie powiedzą, że Polsat kłamie albo że Jedynka (TVP1) kłamie. W PRL sytuacja była klarowniejsza - w ogóle nie było zaufania do mediów, bo telewizja postrzegana była jako narzędzie władzy. W tym kontekście kluczowa jest wiara odbiorcy w prawdziwość tego, o czym mówi nadawca. I by tę wiarę zbudować, utrzymać albo wzmocnić, nadawca medialny sięga do trzech źródeł: środków pochodzących z przekazu (logos), autorytetu nadawcy (etos) i emocji odbiorcy (patos).

Newsy zaspokajają też inne potrzeby odbiorców. Potrzebę ciągłości, którą opisał Roger Silverstone ${ }^{33}$, badając systematyczne ułożenie wykonywanych codziennie czynności. Okazuje się, że powtarzalność pewnych czynności, w tym regularne oglądanie wiadomości w telewizji, daje ludziom poczucie stałości i stabilności świata zewnętrznego. Potrzeba ciągłości broni nas przed zagrożeniami wynikającymi ze zmienności otaczającej rzeczywistości i lękami związanymi z coraz bardziej stresującym życiem. Oczywiście, z jednej strony, wiadomości wywołują obawy, bo pokazują informacje negatywne, ale z drugiej, starają się te obawy rozwiać. Nie jest bez znaczenia wiedza, że można iść spokojnie spać, bo w ciągu najbliższych godzin nie grozi nam atak terrorystyczny. Interesujące jest to, że oglądanie newsów daje widzowi poczucie kontroli nad tym, co dzieje się w odległej rzeczywistości, mimo że nie ma on na to wpływu. Zauważył to Klaus B. Jensen, badając rolę wiadomości politycznych w życiu ludzi ${ }^{34}$. Oglądanie newsów daje widzowi poczucie kontroli nad tym, co dzieje się w odległej rze-

${ }^{33}$ R. Silverstone, Television and Everyday Life, Routledge, London 1994, cyt. za: S. Allan, Kultura newsów, przeł. A. Sokołowska, Wydawnictwo UJ, Kraków 2004, s. 116.

${ }^{34}$ K.B. Jensen, The Social Semiotics of Mass Communication, Sage Publications, London 1995, p. 85 . 
czywistości, mimo że nie ma on na to wpływu. Ważna dla poczucia ciągłości jest też sama formuła serwisu informacyjnego - przewidywalna struktura programu i niezmienna godzina nadawania ${ }^{35}$.

Oglądanie newsów zaspokaja również potrzebę przynależności ${ }^{36}$ i jest narzędziem budowania więzi społecznych. I tak, po pierwsze, oglądanie newsów włącza odbiorcę w wykreowaną przez nadawcę wspólnotę. Uwaga wszystkich skupiona zostaje na pewnych wybranych elementach rzeczywistości, które stają się przedmiotem zainteresowania, rozmów, refleksji. Po drugie, formułowany przekaz wykorzystuje zasoby wiedzy, które uważa wspólne dla całego audytorium, stąd tak częsta w newsach stereotypizacja i generalizowanie.

W końcu, ludzie oglądają newsy w celach rozrywkowych, dla przyjemność wizualnej - wiadomości pokazują obrazy, które wywołują poczucie naoczności, pokazują kompetentnych, miłych prezenterów, ciekawostki ze świata, informacje sensacyjne, niezwykłe i dziwne.

\section{Środki perswazji - oddziaływanie na odbiorcę}

Wiarygodność nadawcy budują przede wszystkim kompetencja i zaufanie ${ }^{37}$. W przypadku newsów trzeba myśleć o nadawcy na dwóch poziomach - w szerokim sensie jest nim instytucja medialna, w wąskim znaczeniu - dziennikarz, reporter przygotowujący newsa. Wiarygodność nadawcy oznacza więc po pierwsze, wiarygodność stacji telewizyjnej, a po drugie, dziennikarza, który w tym newsie występuje, którego widz widzi i słyszy. Kompetencja oznacza postrzeganie nadawcy w kategoriach posiadania wiedzy, doświadczenia czy bycia autorytetem. Na poziomie instytucji medialnej buduje się ją poprzez działania autoprezentacyjne stacji, która podkreśla swoje zaplecze technologiczne, możliwości techniczne bycia tam, gdzie dzieje się to, co najważniejsze, zasięg czy zasoby ludzkie, jakimi dysponuje. Kompetencja wynika też ze specjalizacji. Z badań Byrona Nassa i Clifforda Reevesa wynika, że informacje oglądane w stacjach specjalistycznych są uznawane za ważniejsze, bardziej treściwe, bardziej interesujące i poważne ${ }^{38}$. W kontekście analizowanych tutaj newsów w Polsce takimi stacjami byłyby TVN24, TVN Bizes i Świat, TVP Info czy Polsat News. Jest to zjawisko analogiczne do tego, z jakim mamy do czynienia w relacjach interpersonalnych. Jeśli

\footnotetext{
${ }^{35}$ S. Allan, dz. cyt., s. 116.

${ }^{36}$ Jedna z podstawowych potrzeb wyróżniona przez Abrahama Maslowa (tenże, Motywacja i osobowość, przeł. J. Radzicki, Wydawnictwo Naukowe PWN, Warszawa 2006, s. 68-69).

37 J.L. Whitehead, Factors Of Source Credibility, „Quarteley Journal of Speech” 1968, No 54, pp. 59-63.

${ }^{38}$ B. Reeves, C. Nass, Media i ludzie, przeł. H. Szczerkowska, PIW, Warszawa 2000, s. 174.
} 
człowiek ma etykietkę ,specjalista”, jest bardziej wiarygodny, pełni rolę autorytetu i łatwiej ulegamy jego perswazji. Podobnie jest w przypadku medium z taką etykietą. Media specjalistyczne wydają się odbiorcom bardziej kompetentne. Etykiety oczywiście mogą być różne (np. „publiczna”, „komercyjna”, „lewacka” czy „Rydzykowa”) i co za tym idzie, różne będą tego konsekwencje dla siły oddziaływania medium. W telewizji jednak dla wiarygodności przekazu ważniejszy niż stacja nadawcza jest człowiek, którego widz ogląda (inaczej niż w prasie, gdzie ważniejszy dla wiarygodności jest tytuł, wydawca niż konkretny autor tekstu. Wynika to z tego, że telewizja podkreśla indywidualność i jest to zasługa obrazu). Jeśli chodzi o kompetencję dziennikarzy, to i tutaj istotnym czynnikiem będzie specjalizacja. Uważny widz newsów wie, że reporterzy specjalizują się w określonej tematyce. Ktoś inny przygotowuje materiały o wydarzeniach politycznych, społecznych, biznesowych, ktoś inny będzie mówił o absurdach otaczającej nas rzeczywistości. Jeśli wielokrotnie usłyszymy informację o tym, że dziennikarka $\mathrm{X}$ jest w Sejmie, w końcu uznamy ją za kompetentną i biegłą w problematyce politycznej. Zaufanie natomiast jest pochodną tego, co wrażeniowe. W przypadku newsów chodziłoby o wrażenie odbiorcy, że nadawca mówi z neutralnego punktu widzenia, a nie skażonego subiektywizmem i ideologią. O przekonanie o rzetelności, faktyczności, dokładności i obiektywizmie praktyk dziennikarskich. Osiągnąć to można poprzez odpowiednie zabiegi na tekście, ale istotną rolę wzmacniającą skuteczność perswazji pełni tutaj też etos nadawcy. Ważnym elementem tego etosu jest społeczne przekonanie o publicznej roli dziennikarza, który działa w służbie i interesie społeczeństwa. Dziennikarz to wszak zawód zaufania społecznego. Dodatkowo, dziennikarze, chcąc wzmocnić to zaufanie, operują środkami wizerunkowymi - a więc chociażby strojem i zachowaniem, które są adekwatne do oczekiwań widza związanych z ich rolą.

Jeśli chodzi o przekaz, to odbiorca uznaje go za prawdziwy, gdy jest on dla niego zrozumiały. A rozumiemy dlatego, że wyciągamy wnioski z przesłanek albo dlatego, że już coś znamy ${ }^{39}$. W newsach , prawdziwe” dla odbiorców oznacza - zgodne z ich wyobrażeniami, wyobrażeniami powszechnymi, odwołujące się do obrazów świata w ich głowach, społecznych relacji, które ich łączą, wierzeń i wartości. Dlatego sposób opowiadania świata jest dość szablonowy, odwołuje się do powszechnych przekonań i stereotypów. Gdy mowa o polityce - pokazuje się ją w kategoriach konfliktu, zderzenia racji; gdy mowa o zbrodni - epatuje się emocjami i szuka odpowiedzi na pytanie, dlaczego ktoś zabił i kto mógł tej zbrodni zapobiec; gdy relacja dotyczy Bożego Narodzenia, musi się w niej znaleźć informacja o lapońskim Świętym Mikołaju. Wiarę w prawdę wspomagają też:

39 J. Wasilewski, A. Skibiński, Prowadzeni stowami. Retoryka motywacji w komunikacji publicznej, Diffin, Warszawa 2008, s. 161. 
- obrazy z miejsca zdarzeń i relacje na żywo, zobaczyć bowiem, o czym była już mowa, to uwierzyć;

- powoływanie się na argumenty z autorytetu w postaci cytatów (wypowiedzi w setkach), ale też tabel, wykresów czy wyników badań;

- argumenty zbudowane według reguł myślenia indukcyjnego. Rzeczywistość w newsach opisuje się przez ciągi konkretnych zdarzeń - od szczegółu do ogółu;

- uruchomienie czynnika identyfikacji nadawcy z odbiorcą. Służy temu wprowadzanie do newsów bohaterów, z którymi widz może się utożsamić, tzw. zwykłych ludzi, którzy są beneficjentami lub ofiarami opisywanych zdarzeń. Wprowadzanie do przekazu pojedynczego przykładu, jak pokazali Elliot Aronson i Anthony Pratkanis ${ }^{40}$, jest skutecznym środkiem perswazyjnym. Dużo skuteczniejszym niż wyniki badań czy dane statystyczne.

Ważnym czynnikiem, wpływającym na skuteczność przekazu, jest sposób jego formułowania. Trzeba pamiętać, że newsy, emitowane w obrębie magazynów informacyjnych, są adresowane do szerokiego kręgu odbiorców o bardzo zróżnicowanych kompetencjach komunikacyjnych, którzy w dodatku odbierają je w sytuacji rozproszenia uwagi. Dlatego tak ważna jest ich struktura, która, jak pisze Maciej Mrozowski, powinna być maksymalnie dostosowana do „struktury ciekawości" odbiorcy ${ }^{41}$. News zbudowany jest zazwyczaj z pięciu segmentów, które są odpowiedziami na pytania: co się wydarzyło, co spowodowało zdarzenie, co może z tego wyniknąć, jakie są uwarunkowania i okoliczności zdarzenia i jakie jest znaczenie tego zdarzenia. Są to więc takie części, jak: opis, przyczyny, skutki, wyjaśnienia i komentarze. Sama kompozycja jednak nie wystarczy. Dziennikarze stosują wiele środków służących zbudowaniu i pobudzeniu uwagi widzów. Są to środki zarówno werbalne, jak i wizualne, nastawione na wywołanie określonego stanu emocjonalnego czy postawy wobec przekazu. Na przykład figury dialogowania: pytania retoryczne i subiectio, słownictwo nacechowane emocjonalnie, metafory i analogie, które pozwalają przybliżyć opisywane obiekty i wpływają na zrozumiałość przekazu, ironię, która jest narzędziem wyrażania ocen $^{42}$. Najważniejszym środkiem budowania emocji w newsie jest jednak obraz. To bowiem obraz jest istotą przekazu telewizyjnego, bez niego nie ma telewizji. Słowo pełni rolę drugoplanową. Perswazyjna funkcja obrazu wynika z psychologii odbioru. Obraz traktujemy jako bardziej wiarygodny, a nawet więcej - jako prawdziwy. Przekonanie o tym, że to, co się widzi, jest prawdą, jest aprioryczne.

\footnotetext{
${ }^{40}$ A. Pratkanis, E. Aronson, Wiek propagandy. Używanie i nadużywanie perswazji na co dzień, przeł. J. Radzicki, M. Szuster, Wydawnictwo Naukowe PWN, Warszawa 2003, s. 91-92.

${ }^{41}$ M. Mrozowski, Media masowe. Władza, rozrywka i biznes, Oficyna Wydawnicza ASPRA-JR, Warszawa 2001, s. 309-314.

${ }^{42}$ B. Sobczak, Informowanie (nie)etyczne. O etyce dziennikarskiej i manipulacji $w$ mediach, [w:] Retoryka i etyka, red. B. Sobczak, H. Zgółkowa, Wydawnictwo Poznańskie, Poznań 2009, s. 195-196.
} 
Ma to niebagatelne znaczenie dla retoryki przekazu, dlatego że zanika zdolność polemiczna wobec ekranu ${ }^{43}$. Nie dyskutuje się z tym, co „widać gołym okiem”. Poza tym, obrazy - ponieważ wyglądają jak rzeczy, które reprezentują - wymagają mniej wysiłku intelektualnego i są łatwiejsze w odbiorze. Sprzyjają też bierności i odbiorowi bezrefleksyjnemu ${ }^{44}$.

Dobór i kompozycja obrazów, z których zbudowane są ujęcia, sekwencje, a w końcu cały felieton, jest więc ważnym narzędziem oddziaływania na odbiorcę. I tak, na przykład można sterować czymś, co potocznie nazywane jest „temperaturą” przekazu, a oznacza stopień zaangażowania emocjonalnego odbiorcy w przekaz. To zaangażowanie będzie mniejsze, im bardziej ogólny będzie plan, w jakim filmuje się obiekty. W planie ogólnym, pełnym, amerykańskim obiekt wtapia się bowiem w otoczenie. Natomiast plany bliższe, tzw. psychologiczne (półzbliżenia, zbliżenia, detale), będą podnosiły „temperaturę” przekazu, bo przykuwają uwagę, zmuszają do koncentrowania się na pewnych fragmentach. W przypadku filmowania ludzi - na oczach, ustach i brwiach, a więc na najbardziej znaczących elementach twarzy w komunikacji interpersonalnej ${ }^{45}$. O tej prawidłowości, jak pisze Kazimierz Żórawski ${ }^{46}$, doskonale wiedzieli już specjaliści od propagandy telewizyjnej w czasach PRL. Operatorzy pracujący na potrzeby programów informacyjnych mieli szczegółowe instrukcje, w jakich planach mogą fotografować członków rządu i funkcjonariuszy partyjnych. „Pierwszego sekretarza wolno było fotografować w półzbliżeniu, członków Biura Politycznego i premiera - w planie średnim, plan amerykański zaś zarezerwowany był dla ministrów i członków Komitetu Centralnego" Również ruchy kamery pełnią ważną funkcję w sposobie budowania opowieści o świecie w newsie. Panorama z natury rzeczy obiektywizuje przekaz, jest bowiem ciągiem odsłaniających się przed widzem fragmentów rzeczywistości, najazd natomiast, ponieważ zawęża pole obserwacji, zmusza widza do koncentracji i ogniskuje jego uwagę na wybranym elemencie rzeczywistości. Z kolei odjazd wzbogaca obraz i zmienia sposób wartościowania - to, co na początku ujęcia wydawało się najważniejsze - staje się fragmentem większej całości ${ }^{48}$. Istotne dla budowania emocji wobec opisywanych obiektów jest także filmowanie z góry lub z dołu. Wysokość, na której mieści się kamera względem fotografowanego obiektu, wyraża stosunek do fotografowanej postaci, pełniąc rolę swoistego komentarza. Fotografowanie z dołu zwiększa gabaryty postaci,

${ }^{43}$ B. Reeves, C. Nass, dz. cyt., wszędzie.

${ }^{44}$ K. Żórawski, Dlugi stół. Skrypt dla dziennikarzy programów informacyjnych, Telewizja Polska S.A., Warszawa 2004, s. 38; B. Reeves, C. Nass, dz. cyt., s. 68.

${ }^{45}$ B. Reeves, C. Nass, dz. cyt., s. 57.

${ }^{46}$ K. Żórawski, dz. cyt., s. 45.

47 Tamże.

${ }^{48}$ Tamże, s. 46-47. 
powoduje, że widzowie odbierają ją jako dominującą, silną i posiadającą władzę, filmowanie z góry zaś powoduje zmniejszenie filmowanego przedmiotu, a w przypadku człowieka pomniejsza jego znaczenie ${ }^{49}$.

\section{Zakończenie}

Nie trzeba dowodzić stale rosnącej roli środków masowego przekazu w życiu publicznym. Wiadomo, że media są nie tylko narzędziem kontroli władzy, bez którego współczesna demokracja byłaby niemożliwa, rolą mediów jest też kreowanie dyskursów publicznych, bo - jak dowodzą socjologowie badający sferę publicznego komunikowania - nie istnieje w świadomości społecznej to, czego w mediach nie $\mathrm{ma}^{50}$. W końcu media, a zwłaszcza telewizja, ze względu na swoją dostępność, są jednym z podstawowych źródeł wiedzy i rozrywki dla ludzi. W telewizji szczególną rolę pełnią newsy. Dla nadawców medialnych magazyny informacyjne są programami flagowymi - wyznaczają markę stacji i jej prestiż. Dla odbiorców - zwłaszcza w ważnych momentach życia społecznego - są jednym z najważniejszych źródeł informacji ${ }^{51}$. Newsy telewizyjne funkcjonują więc w mediach jako jeden z elementów działań strategicznych nadawców medialnych nastawionych na określone cele, w tym cele wizerunkowe, polityczne i ekonomiczne. Newsy powstają jako reakcja na konkretne wydarzenia, zaspokajają potrzebę informacji, ale służą też kreowaniu obrazu świata, skupianiu uwagi na pewnych aspektach rzeczywistości, wartościowaniu jej, przekonywaniu o ważności lub nieważności pewnych zdarzeń. Pełnią funkcje informacyjne, ale też kreacyjne, wzorcotwórcze, stymulacyjne, wartościujące i w końcu estetyczne. Dla osiągnięcia tych celów są odpowiednio konstruowane, z uwzględnieniem specyfiki i potrzeb odbiorcy oraz etosu nadawcy. Są więc aktami retorycznymi - zamierzonymi, celowymi, będącymi odpowiedzią na określoną sytuację (uwarunkowane są historycznie, społecznie i politycznie) i adresowanymi do określonych odbiorców.

\section{Bibliografia}

Allan S, Kultura newsów, przeł. A. Sokołowska, Wydawnictwo UJ, Kraków 2004.

Arystoteles, Retoryka, [w:] tenże, Retoryka. Retoryka dla Aleksandra. Poetyka, przeł. H. Podbielski, Wydawnictwo Naukowe PWN, Warszawa 2004.

49 Tamże, s. 48.

${ }^{50}$ Zob. Rytualny chaos. Studium dyskursu publicznego, red. M. Czyżewski, S. Kowalski, A. Piotrowski, Wydawnictwo AUREUS, Kraków 1997.

${ }^{51} \mathrm{P}$. Francuz, O rozumieniu telewizyjnych audycji informacyjnych, „Zeszyty Telewizyjne” 2005, nr 8, s. 37. 
Bauer Z., Gatunki dziennikarskie, [w:] Dziennikarstwo i świat mediów, red. Z. Bauer, E. Chudziński, Universitas, Kraków 2000, s. 143-173.

Bitzer L.F., The Rhetorical Situation, „Philosophy \& Rhetoric” 1968, No 1, pp. 1-14.

Bourdieu P., O telewizji. Panowanie dziennikarstwa, przeł. K. Sztandar-Sztanderska, A. Ziółkowska, red. M. Jacyno, Wydawnictwo Naukowe PWN, Warszawa 2009.

Campbell K.K., Huxman S.S., Burkholder T.R., The Rhetorical Act. Thinking, Speaking and Writing Critically, Wadsworth, Belmont 2003.

Campbell K.K., Modern Rhetoric, [in:] Encyclopedia of Rhetoric, ed. T.O. Sloane, Oxford University Press, New York 2001.

Czyżewski M., Dunin K., Piotrowski A., Cudze problemy. O ważności tego, co nieważne. Analiza dyskursu publicznego w Polsce, Wydawnictwa Akademickie i Profesjonalne, Warszawa 2010.

Francuz P., O rozumieniu telewizyjnych audycji informacyjnych, „Zeszyty Telewizyjne” 2005, nr 8, s. 19-35.

Fras J., Dziennikarski warsztat językowy, Wydawnictwo UWr, Wrocław 1999.

Furman W., Kaliszewski A., Wolny-Zmorzyński K., Gatunki dziennikarskie. Specyfika ich tworzenia i redagowania, Wyższa Szkoła Zarządzania w Rzeszowie, Rzeszów 2000.

Gajda J., Media w edukacji, Oficyna Wydawnicza Impuls, Gdańsk 2007.

Http://www.tnsglobal.pl/informacje/telewizja-trzyma-sie-mocno-nowe-urzadzenia-przynoszanowe-wzorce-ogladania-infografika/ [dostęp: 21.03.2015].

Http://wyborcza.pl/1,76842,15095765,Dla_60_proc_Polakow_TVP_jest_dobra_telewizja_publiczna_.html [dostęp: 21.03.2015].

Iłowiecki M., Krzywe zwierciadło. O manipulacji w mediach, Wydawnictwo Archidiecezji Lubelskiej Gaudium, Lublin 2003.

Jensen K.B., The Social Semiotics of Mass Communication, Sage Publications, London 1995.

Karwat M., Medialna mitologia faktów, [w:] Współczesne oblicza mediów, red. J. Marszałek-Kawa, Wydawnictwo Adam Marszałek, Toruń 2005, s. 44-69.

Kudra A., News jako funkcja, „Acta Universitatis Lodziensis. Folia Literaria Polonica” 2010, nr 13, s. 399-404.

Liberek J., Informacja czy manipulacja? Jak „,Gazeta Wyborcza” pisze o Kościele, „Więź” 1992, nr 11, s. 21-25.

Lisowska-Magdziarz M., Media powszednie. Środki komunikowania masowego i szerokie paradygmaty medialne $w$ życiu codziennym Polaków u progu XXI wieku, Wydawnictwo UJ, Kraków 2008.

Maslow A., Motywacja i osobowość, przeł. J. Radzicki, Wydawnictwo Naukowe PWN, Warszawa 2006.

Maziarski J., Informacja, [w:] Encyklopedia wiedzy o prasie, red. J. Maślanka, Ossolineum, Wrocław 1976, s. 107-109.

Miś L., Demonstracje retoryczne w telewizyjnym programie informacyjnym „Fakty” - TVN, [w:] Sztuka perswazji. Socjologiczne, psychologiczne i lingwistyczne aspekty komunikowania perswazyjnego, red. R. Karpiel, K. Leszczyńska, Zakład Wydawniczy „Nomos”, Kraków 2004, s. 323-334.

Mrozowski M., Media masowe. Władza, rozrywka i biznes, Oficyna Wydawnicza ASPRA-JR, Warszawa 2001.

Mrozowski M., Telewizyjne programy informacyjne - polskie i zagraniczne (analiza porównawcza), „Studia Medioznawcze” 2009, nr 3, s. 27-49. 
Palczewski M., Cała prawda o newsie. Definicja - granice poznania - konteksty, [w:] Teorie komunikacji i mediów, t. 4, red. M. Graszewicz, J. Jastrzębski, Oficyna Wydawnicza ATUT, Wrocław 2011.

Pisarek W., Podstawy retoryki dziennikarskiej, [w:] Dziennikarstwo i świat mediów. Nowa edycja, red. Z. Bauer, E. Chudziński, wyd. 4 zm., uzup., rozszerz., Universitas, Kraków 2008, s. 361-377.

Pratkanis A., Aronson E., Wiek propagandy. Używanie i nadużywanie perswazji na co dzień, przeł. J. Radzicki, M. Szuster, Wydawnictwo Naukowe PWN, Warszawa 2003.

Reeves B., Nass C., Media i ludzie, przeł. H. Szczerkowska, PIW, Warszawa 2000.

Rytualny chaos. Studium dyskursu publicznego, red. M. Czyżewski, S. Kowalski, A. Piotrowski, Wydawnictwo AUREUS, Kraków 1997.

Schramm W., The Nature of News, „Journalism Quarterly” 1949, No 26, pp. 259-269.

Silverstone R., Television and Everyday Life, Routledge, London 1994.

Sobczak B., Informowanie (nie)etyczne. O etyce dziennikarskiej i manipulacji w mediach, [w:] Retoryka i etyka, red. B. Sobczak, H. Zgółkowa, Wydawnictwo Poznańskie, Poznań 2009, s. $183-201$.

Szulczewski M., Informacja, [w:] Teoria i praktyka dziennikarstwa. Wybrane zagadnienia, red. B. Golka, M. Kafel, Z. Mitzner, PWN, Warszawa 1964, s. 91-97.

Tetelowska I., Informacja jako odrębny gatunek prasowy, [w:] taż, Szkice prasoznawcze, Ośrodek Badań Prasoznawczych, Kraków 1972.

Wasilewski J., Skibiński A., Prowadzeni słowami. Retoryka motywacji w komunikacji publicznej, Diffin, Warszawa 2008.

Whitehead J.L., Factors Of Source Credibility, „Quarteley Journal of Speech” 1968, No 54, pp. 59-63.

Wojtak M., Gatunki prasowe, Wydawnictwo UMCS, Lublin 2004.

Worsowicz M., ,,Mam newsa!’, czyli o problemie naukowców i marzeniu dziennikarzy, [w:] News wobec wyzwań XXI wieku, red. M. Palczewski, M. Worsowicz, Akademia Humanistyczno-Ekonomiczna, Łódź 2010, s. 9-24.

Zwoliński A., Słowo w relacjach społecznych, WAM, Kraków 2003.

Żórawski K., Dlugi stół. Skrypt dla dziennikarzy programów informacyjnych, Telewizja Polska S.A., Warszawa 2004.

\section{Barbara Sobczak}

\section{News as a Rhetorical Act}

(Summary)

This article presents television news as a rhetorical act. Television news is understood as an account of an event usually comprising of a short introduction and a few minutes of film footage (sometimes referred to as the editorial), created as a result of the work of reporters, broadcast on television, usually as one of the elements in the structure of a news magazine, but also as an element of the programme blocks of news television channels. Television news functions in the media as one of the elements of the strategic actions of media broadcasters, focused on specific purposes, including image-building and political and economic goals. News is created as a response to specific events, 
it fulfils the need for information, but also serves the creation of a certain image of the world, focusing attention on certain aspects of reality, evaluating it, persuading viewers of the importance or unimportance of certain events. It plays an informative, creative, conceptual, stimulating, evaluative and ultimately aesthetic role. In order to achieve these objectives it is appropriately constructed, taking into account the characteristics and needs of the recipient and the ethos of the broadcaster. In this sense, it is therefore a "rhetorical" act - intentional, deliberate, constituting a response to a specific situation (it is historically, socially and politically conditioned) and addressed to specific recipients.

Key words: news, rhetorical act, television, persuasion, information. 